\title{
Ranah Afektif Dalam Evaluasi Pendidikan Agama Islam, Penting Tapi Sering Terabaikan
}

Ahmad Darmadji ${ }^{1}$

\begin{abstract}
This paper discusses the neglectedness of affective aspect on study evaluation of Islamic Religion Education course (Pendidikan Agama Islam) at higher education institution. It is found that the neglectedness of affective aspect is caused by some critical factors: 1) different perspective among scholars on what aspect of affection that cannot be measured, for example: faith; 2) the learning objective of Islamic Religion Education course is too ideal, that make it difficult to measure; 3) vast majority of Islamic Religion Education lecturer are unable to develop good teaching instruments which cover affective aspect; and 4) the students-lecturers ratio are too wide and far from ideal. To solve this problem, some suggestions are proposed; strengthening the good understanding of affective aspect on Islamic Religion Education among lecturers; and enriching evaluation design and model to reveal affective aspect of students.
\end{abstract}

Keywords: Islamic Religion Education course, affective evaluation, evaluation design.

\footnotetext{
${ }^{1}$ Penulis adalah dosen tetap Program Studi Pendidikan Agama Islam Fakultas Ilmu Agama Islam UII
}

\section{A. Pendahuluan}

Sebagaimana dimaklumi bersama bahwa pendidikan agama Islam (PAI) -bahkan pendidikan apapun - adalah sebuah proses yang melibatkan sejumlah unsur. Di antaranya unsur insani sebagai subyek (peserta didik dan pendidik) serta orang lain di sekitarnya, dan unsur non-insani seperti tujuan, materi, media pendidikan, sarana prasarana pendukung dan lingkungan di mana proses pendidikan dilakukan. Demikian pula ketercapaian tujuan dan hasil pendidikan dipengaruhi banyak faktor, mulai faktor proses hingga faktor lain sebagaimana disebutkan di atas. Tercapai-tidaknya tujuan tersebut juga perlu diketahui banyak pihak, mulai pendidik dan peserta didik hingga masyarakat luas. Ketercapaian tujuan dan hasil pendidikan tersebut antara lain diketahui melalui proses penilaian dan evaluasi.
Selain itu juga dimaklumi bahwa tujuan dan hasil pendidikan setidaknya diharapkan mencakup tiga ranah penting: kognitif, psikomotorik dan afektif sebagaimana lebih sering dikenal dengan Taxonomi Bloom (1956). Anderson (1981) sependapat dengan Bloom bahwa ranah di atas sesuai dengan karakteristik atau tipikal manusia dalam berpikir, berbuat dan berperasaan. Tipikal berpikir berkaitan dengan ranah kognitif yaitu yang berhubungan dengan cara berfikir yang khas; tipikal berbuat berkaitan dengan ranah psikomotor, yaitu yang berhubungan dengan cara bertindak yang khas; dan tipikal perasaan berkaitan dengan ranah afektif. Ranah afektif yaitu cara yang khas dalam merasakan atau mengungkapkan emosi, dan mencakup watak perilaku seperti perasaan, minat, sikap, emosi, atau nilai. Ketiga ranah tersebut merupakan karakteristik manusia 
sebagai hasil belajar dan proses pendidikan pada umumnya (Anderson, 1981: 44). Pada konteks ini, karakteristik tersebut dipahami sebagai kualitas yang menunjukkan cara-cara khusus manusia dalam berfikir, bertindak dan merasakan dalam berbagai suasana (Zuchdi, 2008: 22).

Sebagaimana disebutkan sebelumnya bahwa untuk mengetahui perkembangan tujuan pendidikan dan hasil belajar, diperlukan penilaian dan evaluasi secara menyeluruh, sistematik, sistemik dan terstandar. Standar penilaian pendidikan pada umunya adalah standar yang berkaitan dengan mekanisme, prosedur dan instrumen penilaian hasil belajar peserta didik. Lebih lanjut ditegaskan bahwa penilaian pendidikan pada jenjang pendidikan tinggi khususnya, terdiri atas: (1) penilaian hasil belajar oleh pendidik; dan (2) penilaian hasil belajar oleh satuan pendidikan tinggi.

Terkait dengan penilaian dan evaluasi hasil belajar bidang PAI di perguruan tinggi umum (PTU), sercara formal sistem evaluasi PAI merujuk pada sistem penilaian program mata kuliah dasar umum (MKDU) yang menerapkan prinsip-prinsip perolehan secara berimbang antara tiga komponen. Ketiga komponen dimaksud adalah: (1) perolehan pengetahuan dan pemahaman; (2) pembentukan keterampilan intelektual dan hubungan antar pribadi, dan (3) pembentukan dan pengamalan nilai (Syahidin, 2010: 1). Ketiga komponen tersebut mencerminkan konsepsi pembinaan kepribadian secara menyeluruh, berimbang dan berkesinambungan. Prinsip di atas perlu dijabarkan secara operasional sehingga hasil pendidikan PAI dapat dievaluasi dengan baik.

Selama ini evaluasi PAI di PTU pada umumnya baru sampai pada pengukuran aspek intelektual-kognitif secara formal seperti ujian tengah semester (UTS) dan ujian akhir semester
(UAS), sementara aspek perubahan tingkah laku (psikomotorik) dan afektif belum dilakukan secara memadai. Disadari juga bahwa ranah afektif merupakan ranah atau domain yang sering terabaikan, dan bahkan hal ini terjadi hampir pada semua jenjang atau satuan pendidikan.

Dengan gambaran singkat di atas, penulis terdorong untuk mengupas mengapa hingga saat ini keterabaian ranah afektif itu masih terjadi? Upaya apa yang dapat dilakukan untuk meminimalisir keterabaian ranah afektif sebagaimana disinggung di atas? Tulisan ini diharapkan menjadi bagian dari kontribusi dan partsipasi penulis dalam mengurangi keterabaian ranah afektif khususnya dalam proses pendidikan dan penilaian PAI pada perguruan tinggi umum (PTU). Guna mendukung pembahasan di atas, tulisan ini juga memuat tinjauan tentang mata kuliah PAI di PTU, tinjauan teori ranah afektif dan penilaian/ evaluasi ranah afektif.

\section{B. Pembahasan}

\section{PAI sebagai Mata Kuliah Dasar Umum (MKDU): Tinjauan Sekilas}

Sesuai dengan ketetapan Badan Standar Nasional Pendidikan (BSNP) bahwa Pendidikan Agama -termasuk PAI pada semua jenjang atau satuan pendidikan - dimaksudkan untuk peningkatan potensi atau kemampuan spiritual dan membentuk peserta didik agar menjadi manusia yang beriman dan bertakwa kepada Tuhan Yang Maha Esa dan berakhlak mulia. Akhlak mulia mencakup etika (baik-buruk, hakkewajiban), budi pekerti (tingkah laku), dan moral (baik-buruk menurut umum) sebagai perwujudan dari pendidikan (BSNP, 2006: 3).

Hal demikian tidak terkecuali PAI pada perguruan tinggi umum (PTU) yang ditetapkan sebagai salah satu mata kuliah dasar umum 
(MKDU) dengan bobot 2 SKS. Kendati dengan alokasi waktu yang sangat terbatas, namun tidak jarang PTU menggantungkan harapan yang cukup tinggi sehingga setelah menempuh mata kuliah PAI diharapkan mahasiswanya memiliki kompetensi yang memadai dalam bidang agama Islam. Sebuah PTUN dalam silabi PAI-nya antara lain menetapkan bahwa setelah mengikuti mata kuliah PAI diharapkan mahasiswa memiliki kompetensi sebagai berikut:

(1) Mahasiswa menguasai ajaran Islam dan menjadikannya sebagai sumber nilai, pedoman dan landasan berfikir dan berperilaku dalam menerapkan ilmu dan profesi yang dijalaninya.

(2) Menjadikan "capital intellectual" yang beriman dan bertaqwa kepada Allah I, berakhlak mulia dan berkepribadian Islami (Sumarna, 2009: 1).

Bila ruang lingkup materi PAI umumnya mencakup Al-Qur'an-Hadits, Aqidah, Akhlak, Fiqih, Tarikh dan Kebudayaan Islam, namun pada sejumlah PTU cakupan materinya diperluas, kendati dengan alokasi waktu yang sangat terbatas. Keterbatasan alokasi waktu misalnya dicoba diatasi dengan dilakukannya program tutorial PAI pada semester sebelumnya dan menjadi prasyarat bagi mahasiswa yang mengambil mata kuliah PAI, di samping prasyarat lain seperti terampil dan benar dalam membaca Al-Qur'an. Sebuah PTUN misalnya dalam silabus mata kuliah PAI-nya menetapkan materi PAI dengan cakupan sebagai berikut:

(1) Metode Memahami Islam.

(2) Manusia, Agama dan Islam.

(3) Al-Qur'an: Memahami dan Menghampirinya.

(4) Al-Hadits: Sumber Kedua Ajaran Islam

(5) Ijtihad: Sumber dan Metodologi Hukum Islam
(6) Tauhidullah: Menghayati Kehadiran Allah

(7) Dzikir, Shalat dan Doa

(8) Cinta, Akhlaq dan Amal Sholeh

(9) Amar Ma'ruf Nahyi al-Munkar

(10) Jihad

(11) Keindahan Hidup Setelah Mati

(12) Tasawuf dan Tharikat

(13) Konsep Keluarga dalam Islam (Sumarna, 2009: 1).

Demikian gambaran sekilas kedudukan mata kuliah PAI yang pada satu sisi sejajar dengan mata kuliah dasar umum (MKDU) lainnya, namun di sisi lain mempunyai keluasan materi dan misi yang sedemikian luas karena hampir mencakup semua sisi kehidupan. Dan karena cakupan materi yang demikian luas pulalah antara lain disinyalir timbulnya kelemahan atau kekurangjelasan tujuan ranah afektif yang dirumuskan sebagian besar dosen atau pendidik PAI, disamping disadari bahwa tujuan afektif lebih sulit diukur bila dibandingkan dengan ranah kognitif maupun psikomotorik (Daradjat, 2010: 1).

\section{Teori dan Perkembangan Ranah Afektif}

Sebagaimana dimaklumi bersama bahwa PAI merupakan salah satu mata kuliah yang sarat dengan ranah afektif. Sementara karakteristik afektif setidaknya memiliki tiga kriteria, yakni: (a) melibatkan perasaan dan emosi seseorang; (b) bersifat khas; dan (c) memliki intensitas, arah dan target atau sasaran.

Intensitas merupakan tingkat atau kekuatan suatu peristiwa, perilaku, atau emosi/ perasaan. Misalnya beberapa perasaan dianggap lebih kuat dari perasaan lain, seperti "cinta" bagi sebagian orang dianggap lebih kuat dari sekedar "sayang". Arah perasaan bisa positif (perasaan baik) atau sebaliknya (negatif). Misalnya, 'senang' dianggap perasaan yang positif, sedangkan 'benci' merupakan perasaan negatif. Sedangkan target atau sasaran mengacu 
pada objek, aktivitas, atau ide sebagai arah dari perasaan.

Arah dan intensitas perasaan dapat digambarkan sebagai sesuatu yang kontinum. Titik tengah kontinum tersebut merupakan titik netral, dan dari titik tengah ke arah tertentu merupakan arah positif serta sebaliknya merupakan arah negatif. Anderson (1981: 4) mengilustrasikan sebagai berikut:

\begin{tabular}{|c|c|c|c|c|c|c|}
\hline Negatif & & & Netral & & & Positif \\
\hline Parman & Rose & Iwan & Hilmi & Susi & Siti & Satrio \\
\hline
\end{tabular}

Ilustrasi kontinum sikap peserta didik terhadap mata kuliah tertentu.

Bila 'sikap' dikaitkan dengan kebutuhan individu, maka setiap individu memiliki kebutuhan yang berbeda tingkatannya. Glare W. Grave mengembangkan hirarki kebutuhan individu pada lima tingkat sebagai berikut: (1) kebutuhan fisiologis, (2) kebutuhan keselamatan, (3) kebutuhan sosial, (4) kebutuhan harga diri, dan (5) kebutuhan aktualisasi diri. Terdapat individu yang mengutamakan tingkat kebutuhan tertentu kendati bagi individu lain kebutuhan tersebut berada pada tingkat yang lebih rendah sebagaimana tergambar pada dilustrasi gambar 2 berikut ini. Ilustrasi ini menunjukkan struktur kebutuhan sosial lebih besar dari kebutuhan lainnya.

\begin{tabular}{|c|}
\hline \multicolumn{1}{|c|}{ Aktualisasi Diri } \\
\hline Harga Diri \\
\hline \multicolumn{1}{|c|}{ Sosial } \\
\hline Keselamatan \\
\hline Fisiologis \\
\end{tabular}

\section{Gambar 2:}

Struktur kebutuhan sosial merupakan kebutuhan yang paling besar, kendati bukan merupakan kebutuhan tingkat paling tingi (Hersey \& Blanchard, 1993: 37)

Pada perkembangan dan kondisi yang lain, struktur kebutuhan harga diri dan aktualisasi diri biasanya menjadi kebutuhan yang paling besar. Hal ini terjadi bila tiga kebutuhan di bawahnya sudah relatif terpenuhi. Dengan demikian strukturnya dapat digambarkan sebagaimana pada gambar 3 berikut:

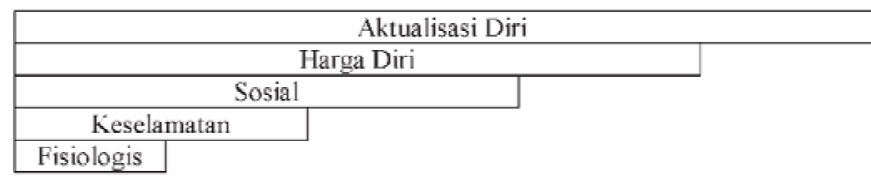

Gambar 3:

Struktur kebutuhan aktualisai diri dan harga diri Merupakan dua puncak kebutuhan yang paling besar (Hersey \& Blanchard, 1993: 38)

Teori perkembangan afektif salah satunya diformulasikan oleh Dupont pada tahun 1976an di mana dasar teori yang dikembangkannya sesuai dengan model perkembangan kognitif dari Piaget. Konsep utama teorinya adalah sebagai berikut:

a) Afeksi adalah getaran refleksi disertai perubahan psikologis dan tendensi bertindak.

b) Perkembangan afektif memiliki komponen struktur dan dan organisasional di mana hal ini menimbulkan respon afektif yang tidak dapat diulang.

c) Perkembangan afektif terdiri dari enam tahap sebagai berikut (Lecapitaine, 1980: 9):

\begin{tabular}{|c|l|l|}
\hline No. & \multicolumn{1}{|c|}{ Tahap } & \multicolumn{1}{c|}{ Karakteristik } \\
\hline 1 & Impersonal & $\begin{array}{l}\text { Pribadi yang tidak jelas (afek yang masih } \\
\text { menyebar) }\end{array}$ \\
\hline 2 & Heteronomi & Pribadi yang jelas (afek unilateral) \\
\hline 3 & Antarpribadi & Pribadi-teman sejawat (afek mutual) \\
\hline 4 & Psikologis-personal & $\begin{array}{l}\text { Afek yang dapat dibedakan satu sama lain } \\
\text { (afek interaktif yang kompleks) }\end{array}$ \\
\hline 5 & Otonomi & $\begin{array}{l}\text { Pusat afek di sekitar konsep abestrak tentang } \\
\text { otonomi diri dan orang lain (afek yang } \\
\text { didominasi oleh sifat otonomi) }\end{array}$ \\
\hline 6 & Integritas & $\begin{array}{l}\text { Pusat afek di sekitar konsep abstrak integritas } \\
\text { diri dan orang lain }\end{array}$ \\
\hline
\end{tabular}

Tabel 1:

Tahap Perkembangan Afektif

Sumber: Lecapitaine, 1980: 9.

Perlu dipahami pula bahwa pengembangan karakteristik afektif pada peserta didik memerlukan upaya secara sadar dan sistematis. 
Terjadi-tidaknya proses kegiatan pembelajaran dalam ranah afektif dapat diketahui dari tingkah laku peserta didik yang menunjukkan adanya kesenangan belajar misalnya. Perasaan, emosi, minat, sikap dan apresiasi yang positif menimbulkan tingkah laku yang konstruktif dalam diri peserta didik. Perasaan dapat mengontrol tingkah laku, sedangkan pikiran (kognisi) seringkali tidak (Anderson, 1981: 17).

\section{Tingkatan Ranah Afektif}

Tingkatan ranah afektif menurut taksonomi Krathwohl (1964) setidaknya mencakup lima tingkat, yaitu: receiving (pengenalan), responding (pemberian respon), valuing (penghargaan), organization (pengorganisasian), dan characterization (pengamalan). Kelimanya merupakan hal yang hirarkis dan dapat digambarkan sebagai berikut:

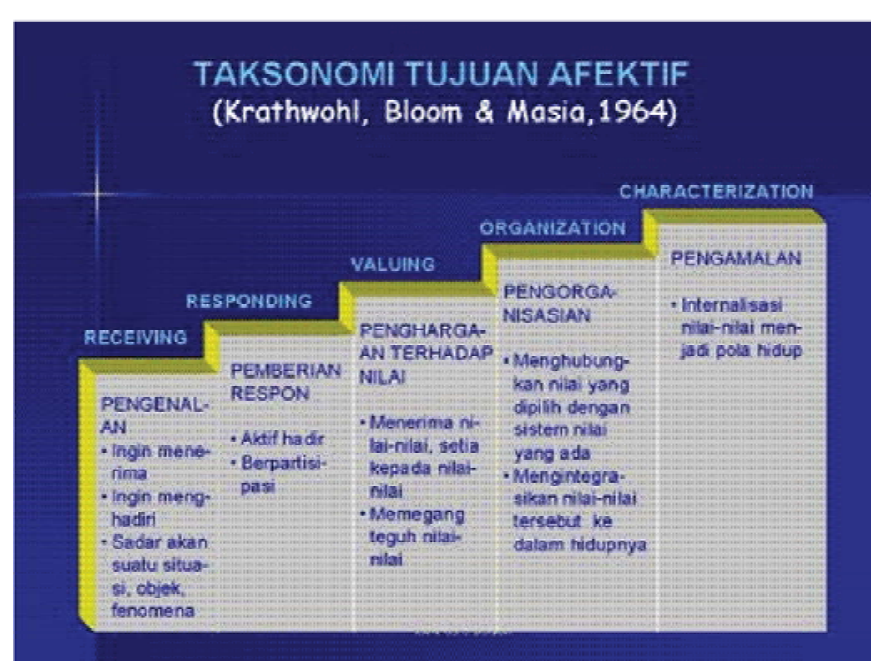

Gambar 4:

Tingkatan ranah afektif

Pada tingkat receiving atau attending, peserta didik memiliki keinginan memperhatikan suatu fenomena khusus atau stimulus. Tugas pendidik mengarahkan perhatian peserta didik pada fenomena yang menjadi objek pembelajaran afektif. Misalnya pendidik mengarahkan peserta didik agar senang membaca, senang bekerjasama, dan sebagainya sesuai dengan pokok bahasan dalam PAI. Kesenangan ini akan menjadi kebiasaan, dan hal ini yang diharapkan, yaitu kebiasaan yang positif.

Responding merupakan partisipasi aktif peserta didik, yaitu sebagai bagian dari perilakunya. Pada tingkat ini peserta didik tidak saja memperhatikan fenomena khusus tetapi ia juga bereaksi. Hasil pembelajaran pada ranah ini menekankan pada pemerolehan respon, berkeinginan memberi respon, atau kepuasan dalam memberi respon. Tingkat yang tinggi pada kategori ini adalah minat, yaitu hal-hal yang menekankan pada pencarian hasil dan kesenangan pada aktivitas khusus. Misalnya senang membaca Al-Qur'an dan mendalami petunjuk di dalamnya, senang membantu, senang terhadap kebenaran dan sebagainya.

Tingkat valuing melibatkan penentuan nilai, keyakinan atau sikap yang menunjukkan derajat internalisasi dan komitmen. Derajat ini rentangnya mulai dari menerima suatu nilai, misalnya keinginan untuk meningkatkan keterampilan, sampai pada tingkat komitmen. Valuing atau penilaian berbasis pada internalisasi dari seperangkat nilai yang spesifik. Hasil belajar pada tingkat ini berhubungan dengan perilaku yang konsisten dan stabil agar nilai dikenal secara jelas. Dalam tujuan pembelajaran PAI, penilaian ini diklasifikasikan sebagai sikap keberagamaan.

Pada tingkat organization, nilai satu dengan nilai lain dikaitkan, konflik antar nilai diselesaikan, dan mulai dibangun sistem nilai internal yang konsisten. Hasil pembelajaran pada tingkat ini berupa konseptualisasi nilai atau organisasi sistem nilai. Misalnya pengembangan filsafat hidup yang Islami secara substansial (tidak fanatik buta terhadap madzhab atau golongan tertentu). 
Tingkat ranah afektif tertinggi adalah characterization nilai. Pada tingkat ini peserta didik memiliki sistem nilai yang mengendalikan perilaku sampai pada waktu tertentu hingga terbentuk gaya hidup. Hasil pembelajaran pada tingkat ini berkaitan dengan pribadi, emosi, dan sosial atau membentuk karakter pribadi muslim yang utuh sebagaimana pribadi Rasulullah Muhammad 䌑.

\section{Penilaian dan Evaluasi Ranah Afektif}

Secara nasional ditetapkan bahwa cara penilaian kelompok pelajaran agama dan akhlak mulia dilakukan dengan: (a) Pengamatan terhadap perubahan perilaku dan sikap untuk menilai perkembangan afeksi dan kepribadian peserta didik; dan (b) Ujian, dan/ atau penugasan untuk mengukur aspek kognitif peserta didik. Sementara teknik penilaiannya dilakukan dengan: (a) tes tertulis, (b) tes praktik, (c) pengamatan, $(d)$ penugasan individual atau kelompok, (e) tes lisan, (f) portofolio, (g) jurnal inventori, (h) penilaian diri, dan (i) penilaian antarteman. Hasil penilaian berupa skor (kuantitatif) untuk aspek kognitif, dan bentuk deskripsi naratif (kualitatif) untuk aspek afektif dan kepribadian (BNSP, 2006: 53).

Menurut Anderson (1980) setidaknya ada dua metode yang dapat digunakan untuk mengukur ranah afektif, yaitu metode observasi dan metode laporan diri. Penggunaan metode observasi berdasarkan pada asumsi bahwa karakteristik afektif dapat dilihat dari perilaku atau perbuatan yang ditampilkan dan/atau reaksi psikologis. Metode laporan diri berasumsi bahwa yang mengetahui keadaan afeksi seseorang adalah dirinya sendiri. Namun hal ini menuntut kejujuran dalam mengungkap karakteristik afektif diri sendiri.

Dalam pengembangan spesifikasi instrumen afeksi dilakukan dengan terlebih dahulu menentukan definisi konseptual yang berasal dari teori-teori yang sesuai. Selanjutnya mengembangkan definisi operasional berdasarkan kompetensi dasar, yaitu kompetensi yang dapat diukur. Definisi operasional ini kemudian dijabarkan menjadi sejumlah indikator. Indikator merupakan pedoman dalam menulis instrumen. Tiap indikator bisa dikembangkan dua atau lebih butir pertanyaan atau pernyataan.

Penilaian dan evaluasi pada ranah afektif, setidaknya terkait dengan lima (5) tipe afektif. Kelima tipe afektif yang penting antara lain adalah sikap, minat, konsep diri, nilai, dan moral. Kelima tipe ini yang biasanya dilakukan penilaian dan/atau pengukuran dikaitkan dengan materi tertentu termasuk materi PAI. Berikut penjelasan singkat kelima tipe afektif tersebut dan instrument yang digunakan.

\subsection{Sikap}

Sikap merupakan suatu kencenderungan untuk bertindak secara suka atau tidak suka terhadap suatu objek. Sikap dapat dibentuk melalui cara mengamati dan menirukan sesuatu yang positif, kemudian melalui penguatan serta menerima informasi verbal maupun nonverbal. Perubahan sikap dapat diamati mulai dari proses pembelajaran, tujuan yang ingin dicapai, keteguhan, dan konsistensi terhadap sesuatu. Penilaian sikap adalah penilaian yang dilakukan untuk mengetahui sikap peserta didik terhadap obyek di atas, bahkan termasuk pada mata kuliah PAI dan sub-sub pokok bahasan yang ada di dalamnya.

Sikap peserta didik terhadap PAI, terhadap sub-sub pokok bahasan di dalamnya bahkan sikap terhadap Islam sebagai agama dan keyakinannya, penting untuk ditingkatkan. Sikap peserta didik ini harus lebih positif setelah peserta didik mengikuti pembelajaran PAI dibanding sebelum mengikuti pembelajaran. 
Perubahan ini merupakan salah satu indikator keberhasilan pendidik dalam melaksanakan proses pembelajaran. Untuk itu pendidik harus membuat rencana pembelajaran termasuk pengalaman belajar peserta didik yang membuat sikap peserta didik terhadap mata pelajaran menjadi lebih positif.

Pertanyaan tentang sikap, meminta responden menunjukkan perasaan yang positif atau negatif terhadap suatu objek tertentu, seperti mata kuliah PAI, pokok bahasan tertentu, sikap ke-Islam-an tertentu, dan lain-lain. Kata-kata yang sering digunakan pada pertanyaan sikap antara lain dengan menyatakan arah perasaan seseorang, misalnya menerima-menolak, menyenangi-tidak menyenangi, baik-buruk, diingini-tidak diingini dan lain sebagainya.

Berikut ini merupakan contoh indikator sikap terhadap mata kuliah PAI:

1) Membaca buku PAI

2) Mempelajari PAI

3) Melakukan interaksi dengan dosen PAI

4) Mengerjakan tugas PAI

5) Melakukan diskusi tentang PAI

6) Memiliki buku PAI

Sementara contoh pernyataan untuk kuesioner yang digunakan sebagai instrumen dalam penilaian antara lain:

1) Saya senang membaca buku-buku PAI

2) Tidak semua orang harus belajar PAI

3) Saya jarang bertanya pada dosen tentang pelajaran PAI

4) Saya tidak senang pada tugas mata kuliah PAI

5) Memiliki buku PAI penting untuk semua peserta didik

\subsection{Minat}

Secara umum 'minat atau keinginan' difahami sebagai kecenderungan hati yang tinggi terhadap sesuatu. Sementara dalam disiplin psikologi 'minat' adalah suatu disposisi yang terorganisir melalui pengalaman yang mendorong seseorang untuk memperoleh objek khusus, aktivitas, pemahaman, dan keterampilan untuk tujuan perhatian atau pencapaian (Departemen Pendidikan Nasional, 1990: 583). Hal penting pada minat adalah intensitasnya. Secara umum minat termasuk karakteristik afektif yang memiliki intensitas tinggi.

Penilaian minat pada konteks PAI antara lain dapat digunakan untuk:

1) Mengetahui minat peserta didik sehingga mudah untuk pengarahan dalam pembelajaran,

2) Menggambarkan keadaan langsung atau keterkaitan antara pokok bahasan tertentu dalam PAI dengan kondisi riil di masyarakat,

3) Mengelompokkan peserta didik yang memiliki minat sama,

4) Acuan dalam menilai kemampuan peserta didik secara keseluruhan dan memilih model atau metode pembelajaran yang tepat,

5) Meningkatkan motivasi belajar peserta didik dan menerapkan nilai-nilai agama/ nilai Islami dalam kehidupan nyata di dalam kehidupan.

Berikut ini contoh indikator minat terhadap mata kuliah PAI:

1) Memiliki catatan mata kuliah PAI.

2) Berusaha memahami PAI

3) Memiliki buku-buku PAI

4) Mengikuti pembelajaran PAI

Berikut adalah contoh pernyataan pada kuesioner untuk penilaian PAI:

1) Catatan mata kuliah PAI saya lengkap

2) Catatan mata kuliah PAI saya terdapat coretan-coretan tentang hal-hal yang penting 
3) Saya selalu menyiapkan pertanyaan sebelum mengikuti pembelajaran PAI

4) Saya berusaha memahami mata kuliah PAI

5) Saya senang mengerjakan soal PAI

6) Saya berusaha selalu hadir pada pembelajaran dan praktikum PAI

\subsection{Konsep Diri}

Menurut Smith, konsep diri adalah evaluasi yang dilakukan individu terhadap kemampuan dan kelemahan yang dimiliki. Target, arah, dan intensitas konsep diri pada dasarnya seperti ranah afektif yang lain. Arah konsep diri bisa positif atau negatif, dan intensitasnya bisa dinyatakan dalam suatu daerah kontinum, yaitu mulai dari rendah sampai tinggi.

Konsep diri ini penting untuk mengembangkan karakter dan kepribadian peserta didik, yaitu dengan mengetahui kekuatan dan kelemahan diri sendiri. Hal ini diharapkan dapat menumbuhkan sikap introspeksi (muhasabatu al-nafs) pada peserta didik, optimism (tafấul) dengan kelebihan yang dimilikinya namun juga tetap sadar dengan kekurangan atau kelemahannya.

Penilaian konsep diri dapat dilakukan dengan penilaian diri. Kelebihan dari penilaian diri adalah sebagai berikut:

1) Pendidik mampu mengenal kelebihan dan kekurangan peserta didik.

2) Peserta didik mampu merefleksikan kompetensi yang sudah dicapai.

3) Pernyataan yang dibuat sesuai dengan keinginan penanya.

4) Memberikan motivasi diri dalam hal penilaian kegiatan peserta didik.

5) Peserta didik lebih aktif dan berpartisipasi dalam proses pembelajaran.

6) Dapat digunakan untuk acuan menyusun bahan ajar dan mengetahui standar input peserta didik.
7) Peserta didik dapat mengukur kemampuan untuk mengikuti pembelajaran.

8) Peserta didik dapat mengetahui ketuntasan belajarnya.

9) Melatih kejujuran dan kemandirian peserta didik.

10) Peserta didik mengetahui bagian yang harus diperbaiki.

11) Peserta didik memahami kemampuan dirinya.

12) Pendidik memperoleh masukan objektif tentang daya serap peserta didik.

13) Mempermudah pendidik untuk melaksanakan remedial, hasilnya dapat untuk instropeksi pembelajaran yang dilakukan.

14) Peserta didik belajar terbuka dengan orang lain.

15) Peserta didik mampu menilai dirinya.

16) Peserta didik dapat mencari materi sendiri.

17) Peserta didik dapat berkomunikasi dengan temannya.

Contoh-contoh indikator konsep diri antara lain sebagai berikut:

1) Memilih sub pokok bahasan yang mudah dipahami

2) Memiliki kecepatan memahami bidang dan pokok bahasan tertentu

3) Mengukur kekuatan dan kelemahan dalam mengkomunikasikan konsep keagamaan tertentu

Sementara itu pernyataan untuk instrumen antara lain dapat dinyatakan sebagai berikut:

1) Saya sulit mengikuti pelajaran PAI

2) Saya mudah memahami pembahasan ijtihad

3) Saya mudah menghapal ayat-ayat AlQur'an tentang hukum

4) Saya mampu membaca dan menerjemahkan hadits hukum dengan baik

5) Saya merasa sulit memahami konsep mahabbah dalam tasawuf 


\subsection{Nilai}

Nilai merupakan suatu keyakinan tentang perbuatan, tindakan, atau perilaku yang dianggap baik dan yang dianggap buruk. Bila sikap mengacu pada suatu organisasi sejumlah keyakinan sekitar objek spesifik atau situasi, maka nilai mengacu pada keyakinan. Target nilai cenderung menjadi ide, atau kadang juga berupa sikap dan perilaku. Arah nilai dapat positif dan dapat negatif. Intensitas nilai dapat dikatakan tinggi atau rendah tergantung pada situasi dan nilai yang diacu. Proses pendidikan dan pembelajaran PAI harus membantu peserta didik menemukan dan menguatkan nilai yang bermakna dan signifikan bagi dirnya untuk memperoleh kebahagiaan personal dan memberi kontribusi positif terhadap masyarakat.

Instrumen aspek nilai sebagai bagian dari ranah afektif bertujuan untuk mengungkap nilai dan keyakinan individu. Informasi yang diperoleh berupa nilai dan keyakinan yang positif dan yang negatif. Hal-hal yang positif ditingkatkan sedang yang negatif dikurangi dan akhirnya dihilangkan.

Sebagian dari indikator nilai antara lain adalah:

1) Memiliki keyakinan akan peran agama dalam kehidupan

2) Menyakini keberhasilan bila melakukan usaha yang optimal

3) Menunjukkan keyakinan atas kemampuan dirinya.

4) Mempertahankan keyakinan akan harapan demi kebaikan bersama

Sementara itu contoh pernyataan untuk kuesioner tentang nilai peserta didik sebagai berikut:

1) Saya berkeyakinan bahwa prestasi belajar peserta didik dapat ditingkatkan.
2) Saya berkeyakinan bahwa kinerja pendidik sudah maksimal.

3) Saya berkeyakinan system pendidikan saat ini belum mampu mengubah tingkat kesejahteraan masyarakat secara merata.

4) Saya berkeyakinan bahwa perubahan selalu membawa masalah.

5) Saya berkeyakinan bahwa hasil yang dicapai peserta didik adalah atas usahanya

\subsection{Moral}

Piaget dan Kohlberg banyak disebut-sebut teorinya tentang perkembangan moral. Bahkan tidak jarang teorinya menjadi landasan dasar dalam proses pendidikan moral (Kohlberg, 1995). Namun teori tersebut bukannya tanpa kritik. Antara lain karena Kohlberg dianggap mengabaikan hubungan antara judgement moral dan tindakan moral. Ia dianggap lebih cenderung pada prinsip moral seseorang melalui penafsiran respon verbal terhadap dilema hipotetikalnya, bukan pada bagaimana sesungguhnya seseorang bertindak atau tindakan moralnya (Miller \& Fielding, 1980: 112).

Seringkali moral berkaitan dengan perasaan salah atau benar terhadap orang lain atau perasaan terhadap tindakan yang dilakukan diri sendiri. Misalnya menipu orang lain, membohongi orang lain, atau melukai orang lain baik fisik maupun psikis. Moral juga sering dikaitkan dengan keyakinan agama seseorang, seperti keyakinan akan perbuatan yang berdosa dan berpahala. Jadi moral berkaitan dengan prinsip, nilai, dan keyakinan seseorang.

Pada konteks PAI dan moralitas Islam, yang diharapkan adalah sampai pada inti moralitas ke-Islam-an yang diyakini secara substansial adalah moralitas universal atau rahmatan lil-'âlamîn. Sejumlah moralitas substansial yang universal dari moralitas Islam 
seperti: kejujuran, integritas, keadilan, kebebasan, penghargaan dan lain-lain. Dengan kata lain, pada konteks keberagamaan ke-Islam-an seseorang, tercipta peserta didik yang tahu dan hafal ajaran agama serta menghayati dan menjadi dasar kepribadiannya.

Sejumlah indikator moral sesuai dengan definisi teoritis antara lain:

1) Memegang janji

2) Memiliki kepedulian terhadap orang lain

3) Menunjukkan komitmen terhadap tugastugas

4) Memiliki Kejujuran dan Integritas

Di antara contoh pernyataan untuk instrumen moral adalah sebagai berikut:

1) Bila saya berjanji pada teman, tidak harus menepati.

2) Bila berjanji kepada orang yang lebih tua, saya berusaha menepatinya.

3) Bila berjanji pada anak kecil, saya tidak harus menepatinya.

4) Bila menghadapi kesulitan, saya selalu meminta bantuan orang lain.

5) Bila ada orang lain yang menghadapi kesulitan, saya berusaha membantu.

6) Kesulitan orang lain merupakan tanggung jawabnya sendiri.

7) Bila bertemu teman, saya selalu menyapanya walau ia tidak melihat saya.

8) Bila bertemu dosen, saya selalu memberikan salam, walau ia tidak melihat saya.

9) Saya selalu bercerita hal yang menyenangkan teman, walau tidak seluruhnya benar.

10) Bila ada orang yang bercerita, saya tidak selalu mempercayainya.

Wujud instrumen yang sering digunakan dalam penilaian tipe afektif di atas antara lain kuisioner dalam bentuk skala, khususnya untuk sikap minat maupun nilai. Sementara skala yang sering digunakan adalah Skala Thurstone, Skala Likert, dan Skala Beda Semantik. Namun demikian dalam tulisan singkat ini, ketiganya tidak dibahas dengan asumsi skala tersebut sudah mafhum (sering digunakan) kendati bukan dalam rangka penilaian atau evaluasi afektif PAI.

\section{Evaluasi PAI di PTU}

Sesuai dengan apa yang penulis alami, sejumlah faktor utama yang menjadi persoalan dalam evaluasi PAI. Sejumlah faktor dimaksud antara lain: pertama, kadang ada perbedaan persepsi tentang batasan materi-materi yang tidak dapat dievaluasi seperti masalah keimanan, kendati sesungguhnya Al-Qur'an telah mengisyaratkan karakter orang-orang yang beriman. Hal ini terjadi tidak hanya pada pelaksanaan evaluasi PAI namun bermula sejak proses pendidikan PAI dilakukan, terlebih bila pendidikan dan pembelajaran dilakukan secara team (team teaching).

Kedua, persoalan juga muncul karena kadang perumusan tujuan PAI terlalu ideal dan terkesan kurang jelas sehingga sulit diukur keberhasilannya. Hal ini dapat difahami karena secara psikologis umumnya orang masih menganggap bahwa agama adalah ajaran 'ideal' dan universal - dan memang bagaimanapun agama adalah ajaran ideal dan universal, minimal bagi pemeluknya. Namun di sisi lain, pandangan idealitas dan universalitas ini menjadikan tujuan mata kuliah PAI kadang menjadi terlalu ideal dan terlalu luas.

Ketiga, secara umum masih ditemukan persoalan klasik berupa kurangnya kemampuan sebagian besar dosen PAI dalam mengembangkan instrumen PAI pada ranah afektif dan psikomotorik, dan lebih sering terbatas pada ranah kognitif. Kendati demikian, memang diakui banyak ahli bahwa evaluasi untuk ranah afektif cenderung 'lebih sulit' bila dibanding ranah lain, namun bukan berarti 
tidak dapat dilakukan secara ideal.

Keempat, persoalan klasik lain sering muncul berupa rasio dosen dengan mahasiswa terlalu jauh sehingga seorang dosen harus mengajar di luar kapasitasnya. Hal ini berdampak pada efektivitas pelaksanaan evaluasi.

Terhadap sejumlah persoalan di atas, setidaknya terdapat sejumlah strategi yang dapat dilakukan dalam usaha meningkatkan proses menilai hasil pendidikan dan pembelajaran PAI secara efektif. Hal ini agar penilaian dapat dilakukan terhadap semua aspek hasil belajar secara serasi dan seimbang sehingga aspek afektif tidak menjadi hal yang terabaikan. Sejumlah strategi dimaksud antara lain: (1) perumusan tujuan yang jelas dan tegas sehingga mudah dievaluasi; (2) pencatatan tingkah laku peserta didik; (3) kesinambungan dalam penilaian; (4) kualitas instrumen dalam penilaian; dan (5) kesesuaian antara aspek yang diukur dengan materi yang disampaikan.

Selain itu disadari bersama bahwa peserta didik PAI di PTU adalah orang dewasa setidaknya dewasa secara biologis. Artinya, terdapat sejumlah hal yang berbeda bila dibanding dengan peserta didik anak-anak dan remaja. Oleh karenanya, evaluasi dan penilaian PAI pada PT dapat dilakukan dengan berbagai cara berikut.

1) Menugaskan mahasiswa untuk melaporkan aktivitas keagamaan masing-masing, baik yang dilakukan di kampus maupun di lingkungan di mana mahasiswa tinggal;

2) Sosio-matriks, yaitu memberikan penilaian dan merangking 5 orang teman-sekelasnya yang paling tinggi sikap kegamaannya, yang di dalamnya antara lain meliputi: (a) cara berpakaian, (b) pelaksanaan shalat, (c) kejujuran, (d) aktivitas keagamaan, (e) menempati janji, (f) pengetahuan dan wawasan keislaman, (g) sopan santun, (h) membaca al-Qur'an, (i) pergaulan dengan teman dalam kehidupan sehari-hari baik dilihat dari bahasa maupun perilakunya, (j) dan lain-lain yang dianggap perlu.

3) Observasi baik langsung maupun tidak langsung untuk mencari informasi dari berbagai sumber tentang perilaku keagamaan mahasiswa peserta didik PAI. Informan yang bisa dijadikan sumber antara lain dapat diperoleh dari dosen-dosen jurusan, himpunan mahasiswa dan tempat tinggal mahasiswa selama masih bisa dilacak.

4) Mengadakan studi sosial keagamaan di sekitar tempat tinggalnya. Mahasiswa ditugaskan untuk mendata kehidupan keagamaan dan kemakmuran masjid yang dekat dengan tempat tinggalnya.

Sementara itu, mekanisme penilaian hasil belajar PAI pada PTU antara lain dapat dilakukan dengan berbagai cara. Sejumlah cara dimaksud antara lain sebagai berikut. Pertama, perancangan penilaian PAI oleh dosen PAI dilakukan saat pengembangan program pembelajaran, baik dalam bentuk silabus maupun rencana pelaksanaan pembelajaran (RPP). Kedua, UTS dan UAS PAI adalah teknik penilaian untuk mengukur ketuntasan penguasaan kompetensi PAI mahasiswa pada tengah semester dan akhir semester. Ujian ini dilakukan oleh dosen PAI di bawah koordinasi satuan pendidikan. Ketiga, penilaian tugas terstruktur dan mandiri adalah teknik penilaian untuk mengukur kedalaman pengamalan ajaran agama dan aktifitas keagamaan mahasiswa dalam keseharian. Keempat, penilaian tugas kelompok melalui diskusi adalah teknik untuk mengukur keluasan pemahaman dan pengetahuan mahasiswa akan ajaran agama Islam. Kelima, penilaian kehadiran adalah teknik untuk menilai komitmen mahasiswa dalam melaksanakan kewajibannya sebagai seorang peserta didik, dan keenam, penilaian sosiometrik 
adalah teknik untuk mengetahui sikap dan amaliah mahasiswa dalam pandangan lingkungannya.

Demikian sekilas sejumlah persoalan dan cara atau mekanisme yang bisa ditempuh sebagai tawaran untuk mengoptimalkan fungsi evaluasi PAI pada PTU. Namun demikian pada kondisi tertentu seorang mahasiswa dinyatakan lulus apabila telah memiliki nilai PAI minimal nilai B dengan sejumlah kompetensi dasar. Kompetensi-kompetensi dasar dimaksud misalnya adalah: mampu menjawab soal UAS dan UTS, mampu membaca al-Qur'an dengan tartil, mampu mempraktekkan gerakan shalat, melaporkan aktivitas keagamaan di mana ia tinggal, mampu menghafal minimal 10 doa harian, kehadiran dan aktivitas di kelas, serta mampu menghafal surat al-Nâs sampai alBayyinah misalnya. Kendati ini masih dianggap minimalis, namun tidak ada kata ukuran minimal yang buruk untuk beranjak ke arah yang lebih baik.

\section{Kesimpulan}

Berdasarkan pembahasan diatas, dapat disimpulkan beberapa poin penting. Bahwa keterabaian ranah afektif pada evaluasi PAI di PTU antara lain disebabkan sejumlah hal, diantaranya: pertama, adanya perbedaan persepsi tentang batasan materi yang tidak dapat dievaluasi seperti masalah keimanan, kedua, perumusan tujuan PAI terlalu ideal dan terkesan kurang jelas sehingga sulit diukur, ketiga, masih kurangnya kemampuan sebagian besar dosen PAI dalam mengembangkan instrumen PAI pada ranah afektif khususnya, dan keempat, rasio dosen dengan mahasiswa terlalu jauh. Untuk mengatasi hal ini antara lain dapat ditempuh dengan memperdalam pemahaman ranah afektif pada PAI sebagai mata kuliah tanggungjawab dosen PAI, memperkaya cara dan mekanisme pelaksanaan evaluasi PAI dengan memperhatikan mahasiswa sebagai peserta didik dewasa.

\section{Daftar Pustaka}

Anderson, Lorin W. 1981. Assessing Affective Characteristic in the Schools. Boston: Allyn and Bacon, Inc.

Anonim. 2006. Panduan Penilaian Kelompok Pelajaran Agama dan Akhlak Mulia. Jakarta: Badan Standar Nasional Pendidikan (BNSP).

Bloom, B. S. ed. et al. 1956. Taxonomy of Educational Objectives: Handbook 1. New York: David McKay.

Daradjat, Zakiah. 2010. Draf Standar Penilaian Pendidikan Agama Islam Pada Perguruan Tinggi Umum. Jakarta: Direktorat Jendral Pendidikan Perguruan Tinggi Islam Kemeterian Agama RI.

Zuchdi, Darmiyati. 2008. Humanisasi Pendidikan. Jakarta: Bumi Aksara.

Departemen Pendidikan Nasional. 1990. Kamus Besar Bahasa Indonesia. Jakarta: Balai Pustaka. 2007. Peraturan Menteri Pendidikan Nasional (Permendiknas) nomor 20 tahun 2007 tentang Standar Penilaian.

Gronlund, N. E. 1978. Stating Objectives for Classroom Instruction 2nd ed. New York: MacMillan Publishing.

Hersey, Paul and Kenneth H. Blanchard. 1993. Management of Organization Behavior. New Jersey: Prentice-Hall, Inc.

Hersh, Miller \& Fielding. 1980. Model of Moral Education: An Appraisal. New York: Longman Inc.

Kohlberg, Lawrence. 1985. Tahap-tahap Perkembangan Moral, terj. John de Santo dan Agus Cremers. Yogyakarta: Kanisius. 
Krathwohl, D. R. ed. et al. 1964. Taxonomy of Educational Objectives: Handbook II, Affective Domain. New York: David McKay.

Lecapitaine, John E. 1980. The Differential Effects of Three Psychological Education Curricula Affective and Moral Development. Boston: Boston University School.
Syahidin. 2010. Draf Standar Penilaian Pendidikan Agama Islam Pada Perguruan Tinggi Umum. Jakarta: Direktorat Jendral Pendidikan Perguruan Tinggi Islam Kemeterian Agama RI

Sumarna, Elan. 2009. Silabus dan Satuan Acara Perkuliahan (SAP) mata kuliah PAI Semester Genap. Bandung: Fakultas Pendidikan Ilmu Pengetahuan Sosial UPI. 